\title{
National succession laws in comparative perspective
}

\author{
Eleanor Cashin Ritaine
}

Published online: 11 April 2013

(C) ERA 2013

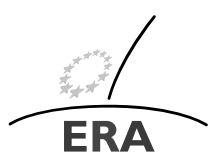

EUROPÄISCHE RECHTSAKADEMIE ACADEMY OF EUROPEAN LAW ACADEMIE DE DROIT EUROPEEN ACCADEMIA DI DIRITTO EUROPEO TRIER - TREVES - TREVIRI

\begin{abstract}
The 2012 EU Regulation on Cross-Border Successions allows EU citizens to choose between at least two possible applicable laws to their succession: the law of their country of residence or the law of their nationality. This paper aims to highlight how substantive succession law issues are treated in a diverse manner throughout Europe and thus increase the need for proactive estate planning when the choice of law is open to the European resident. In particular, the paper provides a pan-European panorama of the national legal rules on successions, forced heirship rights and, the means of transferring the estate.
\end{abstract}

Keywords Successions $\cdot$ Private international law $\cdot$ Estate planning

The 2012 EU Regulation on Cross-Border Successions ${ }^{1}$ shall enter into force in 2015 but it provides for an opt-in alternative as of now. It aims to harmonize the rules governing the conflict of laws applicable to a succession by applying a single law to the inheritance, i.e. the law of the country of the final residence of the deceased by

\footnotetext{
${ }^{1}$ Regulation (EU) No 650/2012 of the European Parliament and of the Council of 4 July 2012 on Jurisdiction, Applicable Law, Recognition and Enforcement of Decisions and Acceptance and Enforcement of Authentic Instruments in Matters of Succession and on the Creation of a European Certificate of Succession, OJEU 27.7.2012, L 201/107.

This article is based on a presentation given at the Conference "Cross-border Successions within the EU”, organised by ERA on 22-23 November 2012 in Trier.

E. Cashin Ritaine, Associate $(\varangle)$

Lalive, PO Box 6569, 1211 Geneva 6, Switzerland

e-mail: eleanor.cashin-ritaine@wanadoo.fr

E. Cashin Ritaine

University of Lorraine, Metz, France
} 
default or alternatively the law of his/her nationality by express choice. This law shall apply to the whole of the succession, no distinction being made between immovable and movable property. ${ }^{2}$

As a result, by allowing EU citizens to choose between at least two possible applicable laws, the law of their country of residence or the law of their nationality, ${ }^{3}$ it becomes paramount for estate planning practitioners to be knowledgeable of the substantive content of succession laws throughout Europe. ${ }^{4}$

The impact assessment preceding the adoption of the Regulation showed that some nationals are more prone than others to reside in a different country than the country of their nationality: this is the case of in particular, Irish, Italian, Portuguese, Greek, Spanish and French nationals. ${ }^{5}$ Alternatively, some countries host a large number of foreigners: Luxembourg (20\% of population), Belgium (5.5\%), Ireland, Sweden and Germany. Additionally, many European citizens have assets in other countries, whether immovable property or bank accounts. ${ }^{6}$ Around 450,000 cross border succession cases ${ }^{7}$ are processed every year in EU Europe and imply cooperation between legal professionals in different countries with often different legal traditions.

A model for such cross-border succession management can be found in Switzerland where such issues were clearly identified in the 1987 Federal Act on Private International law ("PILA"). ${ }^{8}$ In Switzerland, as a rule, Swiss law applies to successions of persons domiciled in Switzerland, unless these persons choose the law of their nationality and have not become Swiss nationals at the time of their demise. ${ }^{9}$ The new EU Regulation adopts a similar but more definite approach, ${ }^{10}$ EU residents of EU member States in which the new Regulation is applicable ${ }^{11}$ are entitled to choose to apply the law of their nationality to their succession. Should such a choice not be made, the law of their country of habitual residence shall apply by default. As a result, succession law practitioners throughout Europe will need to have access

\footnotetext{
${ }^{2}$ Arts. 21 (1) and 23 (1) of the Regulation No 650/2012.
}

${ }^{3}$ If a person has more than one nationality, they may choose the law of any of their nationalities: at the time of their choice or at the time of death (Regulation, art. 22 (1)).

${ }^{4}$ Comp. Van Erp [8], p. 3, who considers that a harmonization of national succession laws is inevitable on certain aspects to allow mutual recognition.

${ }^{5}$ Dörner/Lagarde [1], p. 11.

${ }^{6}$ Dörner/Lagarde [1], p. 12.

${ }^{7}$ European Commission Press Release of 7 June 2012, IP/12/576.

${ }^{8}$ Loi fédérale du 18 décembre 1987 sur le droit international privé (LDIP) du 18 décembre 1987, RS 291.

${ }^{9}$ Article 90 PILA. - Comp. EU Regulation No 650/2012, Art. 22 (1) "A person may choose as the law to govern his succession as a whole the law of the State whose nationality he possesses at the time of making the choice or at the time of death". The EU Regulation does not provide for a change of the law applicable to a succession if the deceased became a national of his/her country of residence after having made a choice to apply the law of his other nationality. Moreover, a person could, even when holding the nationality of his country of residence, choose the law of his/her other nationality to govern his/her succession: Art. 22 (1) "A person possessing multiple nationalities may choose the law of any of the States whose nationality he possesses at the time of making the choice or at the time of death".

${ }^{10}$ As it does not change, even if the testator acquires the nationality of his/her country of residence.

${ }^{11}$ The Regulation No 650/2012 is not applicable in the United Kingdom, Ireland and Denmark (comp. Regulation, recitals 82 and 83 ). 
to succession laws worldwide as the Regulation has a universal effect leading to the application of any law whether or not it is the law of a Member State. ${ }^{12}$

Within Europe, there are essentially four main legal traditions or legal families: ${ }^{13}$ The countries applying common law (essentially England, Wales, Northern Ireland and Ireland), the Romanic civil law group based on the Napoleonic Code (France, Luxembourg, Belgium, Italy, Spain, Portugal), the Germanic civil law group (Germany, Austria and the Eastern European Countries) and finally the Nordic countries (Sweden, Finland, Denmark). A fifth "minority" group belongs to the so-called mixed jurisdictions family (Scotland). It is not possible within the scope of this paper to cover all 27 EU countries plus Switzerland. The present analysis is thus confined to thirteen "representative" countries of each legal tradition such as all countries of the British Iles, France, Belgium and Italy, Germany, Austria and Greece, Sweden and Finland, and Switzerland.

Within these legal traditions, the rules on successions are very diverse and remain steeped in national cultural traditions. ${ }^{14}$ With the new EU Regulation, this shall not change. What the EU Regulation aims to achieve is the clear definition of private international law rules applicable to succession matters throughout the EU. ${ }^{15}$

Private international law rules define the law applicable to the succession which in turn will decide how and to which extent the estate is transferred to heirs.

Under the new Regulation, the law applicable to the succession is either the law of the habitual residence of the deceased ${ }^{16}$ or his/her national law if the deceased has chosen the application of this law. ${ }^{17}$ The Regulation thus unifies for most EU States ${ }^{18}$ the law applicable to a succession. Prior to this Regulation, some countries applied the law of the deceased's nationality, ${ }^{19}$ others the law of domicile ${ }^{20}$ others again distinguished between the types of assets in the succession, ${ }^{21}$ applying the law of the

\footnotetext{
${ }^{12}$ Regulation No 650/2012, Article 20. For a compendium of succession laws throughout Europe: www.successions-europe.eu.

${ }^{13}$ Hertel [2], p. 142.

${ }^{14}$ Dörner/Lagarde [1], p. 5; Van Erp [8], p. 1.

${ }^{15}$ Except to the UK, Ireland and Denmark, see recitals 82 and 83 of the Regulation No 650/2012.

${ }^{16}$ Art. 21 (1) Regulation No 650/2012.

${ }^{17}$ Art. 22 (1) Regulation No 650/2012.

${ }^{18}$ Except the UK, Ireland and Denmark, see recitals 82 and 83 of the Regulation No 650/2012.

${ }^{19}$ Italy: Article 46 para. 1 of the law n 218 of 31 May 1995; Greece, Article 28 Greek Civil Code.

${ }^{20}$ Denmark applies the law of the last domicile of the deceased, Sweden the deceased's nationality whereas Finnish law applies the law of the last domicile if this has been the case for over five years, if not, Finnish law applies the law of the deceased nationality. Comp. Sundstrõm [6], p. 199, 206; Örnsved [4], p. 720.

${ }^{21}$ As a rule Common law countries (UK jurisdictions and Ireland) apply the scission principle to a succession: movable assets depend on the law of the last domicile of the deceased whereas immovable property depends on the situation of the assets. In civil law countries, many situations occur: Under Article 3 of the French Civil Code, the scission principle applies: movables are attached to the law of the last domicile of the deceased whereas immovable property is attached to the law of its situation. This is also the system applied in Belgium (Art. 78 of the law of 16 July 2004 portant le Code de droit international privé) and Luxembourg and Malta. In other European countries, the law of nationality applies to movable property, the lex situs to immovable property (see however Italy, Portugal and Spain: application of the law of nationality).
} 
country of residence to movable property, the lex situs to immovable property. ${ }^{22}$ One of the main changes introduced by the Regulation is the application of a single law to the whole of the succession excluding the scission principle.

Once the law applicable to a succession has been established, pursuant to Article 23 (2) of the Regulation, this law shall govern in particular:

(a) the causes, time and place of the opening of the succession;

(b) the determination of the beneficiaries, of their respective shares and of the obligations which may be imposed on them by the deceased, and the determination of other succession rights, including the succession rights of the surviving spouse or partner;

(c) the capacity to inherit;

(d) disinheritance and disqualification by conduct;

(e) the transfer to the heirs and, as the case may be, to the legatees of the assets, rights and obligations forming part of the estate, including the conditions and effects of the acceptance or waiver of the succession or of a legacy;

(f) the powers of the heirs, the executors of the wills and other administrators of the estate, in particular as regards the sale of property and the payment of creditors, without prejudice to the powers referred to in Article 29(2) and (3);

(g) liability for the debts under the succession;

(h) the disposable part of the estate, the reserved shares and other restrictions on the disposal of property upon death as well as claims which persons close to the deceased may have against the estate or the heirs;

(i) any obligation to restore or account for gifts, advancements or legacies when determining the shares of the different beneficiaries; and

(j) the sharing-out of the estate.

These issues are substantive law issues. This paper aims to highlight how these issues are treated in a diverse manner throughout Europe and thus increase the need for proactive estate planning when the choice of law is open to the European resident.

To this effect, three issues will be examined here:

- (Section 1) The Legal Rules on Successions (the ab intestat succession),

- (Section 2) Forced Heirship Rights and,

- (Section 3) The Transfer of the Estate.

\section{Legal rules on succession (ab intestat successions)}

Art. 23 (2) of the Regulation provides that the law applicable to the succession shall govern in particular:

(a) the causes, time and place of the opening of the succession;

(b) the determination of the beneficiaries, of their respective shares and of the obligations which may be imposed on them by the deceased, and the determination of other succession rights, including the succession rights of the surviving spouse or partner;

${ }^{22}$ Revillard [5], p. 360, n ${ }^{\circ} 674$ for an extensive list. 
(c) the capacity to inherit;

(d) disinheritance and disqualification by conduct.

The defining of heirs is one of the essential tasks of legislators when regulating $a b$ intestat successions. In all cases where the deceased has not clearly defined who is entitled to a portion of his/her estate, legislators have set up fall-back rules that allow the transmission of the estate to predefined beneficiaries, based on family ties, the so-called legal heirs (Sect. 1.2).

In general, before the succession is settled strictly speaking, the matrimonial property regime between spouses must be settled first. This is a complicating factor (Sect. 1.1).

\subsection{A Complicating factor: the settling of the matrimonial property status}

Depending on the applicable law, the spouses' matrimonial status may allow for a separation of assets (Common law system) or a community of assets acquired during the marriage (Civil law tradition). As a result, the rights of the spouse are given priority to those of the legal heirs.

Should the spouses not have opted for a law applicable to their matrimonial status, some countries may just simply apply the law of the current domicile of the parties. ${ }^{23}$ For example, Swiss law ${ }^{24}$ adopts the law of the current domicile whereas in most other States the first matrimonial domicile ${ }^{25}$ or nationality may be the relevant connecting factors.

In Germanic law countries the law applicable to the matrimonial status is the law of the common nationality at the time of marriage and by default the law of the common domicile. As a rule the assets are separated with however a right to compensation: each spouse is entitled to half of the net gain of the others patrimony. ${ }^{26}$ Therefore in Germany, the share of the estate of the surviving spouse depends on the matrimonial regime. If the couple were married under the legal system of participation in the property acquired after the marriage (Zugewinngemeinschaft), the surviving spouse inherits - alongside the parents of the deceased and their descendants-half of the estate by virtue of inheritance $\operatorname{law}^{27}$ and a quarter as the matrimonial compensatory benefit (all-inclusive). ${ }^{28}$

In Nordic countries, the matrimonial status is attached to the first domicile of the spouses. ${ }^{29}$ Assets are considered to be separated during the marriage, each spouse being entitled to dispose of his/her own assets without the consent of the other spouse.

\footnotetext{
${ }^{23}$ Comp. the Hague Convention of 14 March 1978 which leads to changing the matrimonial status when changing residence.

${ }^{24}$ Article 54 PILA.

${ }^{25}$ Comp. The Hague Convention of 14 March 1978 on the Law Applicable to Matrimonial Property Regimes.

${ }^{26}$ Comp. Swiss law: the increase in value of initial assets is not taken into account.

${ }^{27}$ Germany, §1931, para. 1 BGB.

${ }^{28}$ Germany, §1371, para. 1 BGB.

${ }^{29}$ Or in Denmark, the domicile of the husband at the time of the marriage.
} 
At the liquidation of the matrimonial status, whether by divorce or by death, the assets acquired during the marriage are deemed to be common.

Once the matrimonial property has been attributed to the surviving spouse as per the applicable matrimonial property regime, succession rules stricto sensu are applied to define the heirs of the deceased person.

\subsection{Definitions of heirs/beneficiaries}

When defining legal heirs (1) in most European countries, a clear distinction is made between whether the deceased was married or not, and whether the deceased had children or not.

In practice four main cases may be found (2). A specific regime applies generally to registered partners (3). Furthermore, all European countries contain provisions on the "unworthiness to succeed" (4).

\subsubsection{Legal heirs}

In all European countries family and succession laws have evolved over the past decades integrating the social and economic mutations that have drastically changed the so-called traditional family.

From a sociological standpoint, family ties have changed as the traditional family cell based on marriage has given way to so-called recomposed families following divorce or to families where none of the parents are or have been married. Family relationships of same-sex couples are been recognized in a growing number of European countries leading to new forms of partnerships other than marriage and to the necessity to review succession laws. Additionally, longer life expectancy has changed traditional views on the transmission of assets.

From an economic standpoint, family fortunes now owe more to the acquisition of assets during a lifetime by both spouses than to the transmission of assets from one generation to another: as a result matrimonial property regimes play an important part when allocating the assets of an estate.

Following these sociological and economic mutations, two logics apply to the definition of legal heirs: a traditional logic aiming to transfer assets from one generation to another in a vertical manner; a more modern logic aiming to fulfil economic assistance duties with respect to the surviving spouse (horizontal transfer). ${ }^{30}$

Legislation throughout Europe takes into account these various logics thus creating a kaleidoscope of ways of defining legal heirs. It is however fair to assert that there is a general growing tendency of protecting the surviving spouse, and of recognizing an equal status between all children whether born in wedlock or not, adulterine or adopted. ${ }^{31}$

Throughout Europe, legal heirs are, as a rule, the children of the deceased (descendants), the parents of the deceased (ascendants) and the spouse, whose rights are often largely dependent on the existence of children and/or of parents of the deceased.

\footnotetext{
${ }^{30}$ Tainmont [7], p. 15.

${ }^{31}$ Comp. CEDH, 13 June 1979, Marckx, 1979, Serie A n³1, application of the general principle of nondiscrimination. - Art. 745 Belgian Civil Code.
} 
What varies greatly between the different European legislations is the order of succession or the amounts each legal heir may be entitled to depending on the order of succession.

\subsubsection{Cases}

(1) If the deceased was unmarried and does not have children: legal heirs are parents and/or siblings

In many, if not most, European countries, the inheritance is devolved in equal parts to each of the parents of the deceased and, should they have died before their descendants, to their descendants, i.e. the siblings of the deceased. This is the case in Germany, Austria, Finland, Sweden, England and Wales. ${ }^{32}$

In Ireland however, ${ }^{33}$ the estate shall be distributed between the parents in equal shares if both survive the deceased, but, if only one parent survives, that parent shall take the whole estate.

Some States distinguish between siblings of the whole blood and siblings of the half-blood (England and Wales). ${ }^{34}$ In Northern Ireland ${ }^{35}$ and Scotland, ${ }^{36}$ siblings of the whole and half-blood are equally entitled.

In other countries, the estate is divided between the deceased's parents and any siblings. This division may be in equal shares between the deceased's parents who get half and any brothers and sisters as in Greece, Scotland ${ }^{37}$ and Italy. ${ }^{38}$ Or in unequal shares as in Belgium ${ }^{39}$ or in France: ${ }^{40}$ each parent receives a quarter; the other half is transferred to the brothers and sisters or their descendants.

As a rule, if a sibling is already deceased, he/she is represented by his/her descendants per stirpes. If the mother and father die before the deceased, the siblings of the deceased or their descendants succeed them, to the exclusion of other relatives, ascendants or collateral relatives. ${ }^{41}$

If the deceased does not leave any siblings or descendants of the latter, his/her estate is divided equally between his/her mother and father. ${ }^{42}$

If there are no ascendants or siblings, half of the succession passes to the parentage on the mother's side and the other half passes to the parentage on the father's side (uncle, aunt, cousin).

\footnotetext{
${ }^{32}$ Germany, 1925 BGB; Austria, $§ \$ 735$ and 736 ABGB; Finland, 2:2 PK; Sweden 2:2 ÄB, England and Wales.

${ }^{33}$ Irish Succession Act, 1965, Section 68.

${ }^{34}$ Administration of Estates Act 1925, Section 46.

${ }^{35}$ Administration of Estates Act (Northern Ireland) 1955, Section 14.

${ }^{36}$ Succession (Scotland) Act 1964, Section 2.

${ }^{37}$ Unless the deceased also left a cohabitant who could apply to the court for an award from the estate under Section 29 of the Family Law (Scotland) Act 2006.

${ }^{38}$ Art. 571 of the Italian Civil Code.

${ }^{39}$ Article 748 of the Belgian Civil Code.

${ }^{40}$ Article 738 of the French Civil Code.

${ }^{41}$ Comp. Article 737 of the French Civil Code.

${ }^{42}$ Comp. Article 736 of the French Civil Code.
} 
(2) If the deceased was unmarried and leaves children

The estate is generally divided equally between the children in Germany, Austria, Greece, Belgium, France, Italy, Ireland, England and Wales, Northern Ireland, Finland and Sweden. ${ }^{43}$ The portion of a child who is already deceased reverts to that child's descendants per stirpes (representation).

An exception can be found in Scotland, where the children shall have a right to the whole of the deceased's estate unless the deceased also left a cohabitant who could apply to the court for an award from the estate. ${ }^{44}$

(3) If the deceased was married, but has no children, the share of the estate of the surviving spouse depends on the matrimonial regime and on the survival of the parents or siblings of the deceased

Leaving aside the specificities of matrimonial regimes which render the legal kaleidoscope even more colourful, the surviving spouse may be sole heir or simply receive a portion of the estate alongside the parents of the deceased. Many sub-cases may appear:

- If there are no parents and their descendants and grandparents, the spouse inherits the entire estate in Germany, France, Greece, Belgium, Italy, Finland, ${ }^{45}$ Sweden, ${ }^{46}$ England and Wales, Northern Ireland and Scotland. ${ }^{47}$

- If there are no parents but siblings: Notwithstanding article 757-2 of the Civil Code, in France, if there are no ascendants, the deceased's brothers and sisters or their descendants receive half of the assets included in the succession which were received by the deceased from his/her ascendants by way of a succession or a gift. This is the so-called right of reversion. ${ }^{48}$ All the other assets devolve upon the surviving spouse.

- If the deceased's parents and/or collateral parents are still alive the spouse inherits in variable portions:

In France, ${ }^{49}$ half of the estate devolves upon the spouse, while the mother and father each receive a quarter. ${ }^{50}$ If one of the ascendants is already deceased, the quarter reverts to the spouse.

\footnotetext{
${ }^{43}$ Germany, §1924 BGB; Austria, §732 ABGB; Greece. Article $1813 \S 3$ of the Greek Civil Code; Belgium, Art 745 of the Belgian Civil Code; France, Articles 734 and 735 of the French Civil Code; Italy, Article 566 of the Italian Civil Code; Ireland; England and Wales, Northern Ireland, Administration of Estates Act (Northern Ireland) 1955, Section 8; Finland; Sweden.

${ }^{44}$ Under Section 29 of the Family Law (Scotland) Act 2006.

${ }^{45}$ The deceased's parents inherit, as subsequent heirs, only on the death of the surviving spouse.

${ }^{46} \mathrm{He} / \mathrm{she}$ may freely dispose of his/her inheritance while living or as a result of death.

${ }^{47}$ Germany, §1931, par. 2 BGB; France, article 757-2 of the French Civil Code; Greece, Belgium, Article 745 bis of the Belgian Civil Code; Italy, Art. 583 Civil Code; Finland, 3:1 PK; Sweden , 3:1 ÄB; England and Wales; Northern Ireland, Administration of Estates Act (Northern Ireland) 1955, Section 7; Scotland, Succession (Scotland) Act 1964, Section 2.

${ }^{48}$ Article $757-3$ of the French Civil Code.

${ }^{49}$ Article $757-1$ of the French Civil Code.

${ }^{50}$ Comp. Greece: The spouse inherits half, the rest is shared per capita between the parents and the siblings (Article 1814 of the Greek Civil Code).
} 
In Austria and Italy the surviving spouse obtains $2 / 3$ of the estate, ${ }^{51}$ the remainder passes to the parents and brothers and sisters of the deceased. ${ }^{52}$ Moreover in Austria, the spouse is entitled to the estate set aside for the surviving spouse over and above his/her equal share with the others (it is not part of the estate); this concerns for example the right to reside in the marital home or the right to the household furniture. ${ }^{53}$

In Belgium, ${ }^{54}$ the surviving spouse receives the full ownership of the entitlement of the deceased in the common property and the usufruct on sole assets of the deceased and the other heirs the bare ownership of these sole assets.

In Northern Ireland, ${ }^{55}$ the spouse shall take the movable property and, in addition, $£ 450000$ of the residuary estate. Also, the surviving spouse may buy from the personal representative, the deceased's interest in the dwelling-house.

- Some countries do not grant any right to the ascendants: in Ireland, ${ }^{56}$ the spouse shall take the whole estate.

(4) If the deceased was married and leaves children

All countries deal in different ways with the rights of the children and the rights of the spouse, taking into account the legal matrimonial regime. The rights of the spouse range from full inheritance to simple usufruct, whereas the children may receive the full estate or only a subsidiary inheritance right after the demise of the spouse. Some countries grant an option to the spouse between full ownership rights on a limited part of the estate and usufruct rights on the entire estate.

With respect to ownership rights, some countries define a fixed portion of the estate to the spouse and the children. For example, children may be entitled to $3 / 4$ of the estate in Greece, ${ }^{57}$ to $2 / 3$ in Austria, ${ }^{58}$ to $1 / 2$ in Germany, ${ }^{59}$ or $1 / 3$ in Ireland, ${ }^{60}$ the spouse receiving the remaining portion.

Other countries define the ownership portion of the estate devolving to the spouse depending on the number of children: for example in Italy, ${ }^{61}$ the spouse is entitled to half of the inheritance if there is only one child, a third in other cases.

\footnotetext{
${ }^{51}$ Article 579 of the Italian Civil Code.

${ }^{52}$ Austria, $\$ 757$ ABGB - Article 579 of the Italian Civil Code.

${ }^{53}$ Austria, $\$ 758$ ABGB.

${ }^{54}$ Belgium, Article 747 bis of the Belgian Civil Code.

${ }^{55}$ Administration of Estates Act (Northern Ireland) 1955, Section 7.

${ }^{56}$ Irish Succession Act, 1965, Section 67 (1).

${ }^{57}$ Article 1813 of the Greek Civil Code.

${ }^{58}$ Austria, $\$ 757 \mathrm{ABGB}$ : plus the estate set aside for the surviving spouse over and above his/her equal share with the others.

${ }^{59}$ Germany, §1924, par. 4 BGB.

${ }^{60}$ Mee [3], p. 309.

${ }^{61}$ Art. 581 of the Italian Civil Code.
} 
Some countries only grant a right of use (usufruct or possession rights) to the spouse: For example, in Belgium, the surviving spouse will inherit the usufruct (the right of beneficial ownership) of all the assets comprising the inheritance. ${ }^{62}$ The children inherit the bare ownership in equal shares. ${ }^{63}$ In the same manner, in Finland, the descendants inherit the entire estate. The surviving spouse can, however, retain full possession $^{64}$ of the deceased spouse's estate. ${ }^{65}$

Other countries grant an option to the spouse to benefit from usufruct rights or ownership rights: In France, the spouse may choose between the usufruct of all the existing assets or the ownership of a quarter of the assets when all the children are born to the same parents and the ownership of a quarter of the assets in the case of one or more children who are not born to the same parents. ${ }^{66}$

Sometimes the spouse inherits with the provision that the estate will be, after the spouse's death, transferred to the children. For example, in Sweden, the surviving spouse receives the entire estate as an encumbered heir. The joint children are the subsequent heirs. ${ }^{67}$ In this case, the spouse is sole heir but descendants have a deferred right.

Some countries distinguish between the types of assets the spouse is entitled to: In England and Wales, if the deceased leaves a spouse (or a civil partner) and children, the surviving husband or wife (or the civil partner) shall take the movable property and, in addition, a statutory legacy of $£ 250000$. The residuary estate (other than the movable property) shall be held by the personal representative as to one half upon trust for the surviving husband or wife during his/her life, and, subject to such life interest, as to the other half, on statutory trust for the children of the deceased. The surviving spouse (or civil partner) has the following elective rights: The surviving spouse (or the civil partner) can ask the capital value of his/her life interest in the residuary estate. Also, the surviving spouse may buy from the personal representative the deceased's interest in the dwelling-house in which the surviving spouse was resident at the time of the deceased's death.

In Scotland, ${ }^{68}$ if the deceased leaves a spouse (or a civil partner) and children, the surviving husband or wife (or the civil partner) shall take as prior rights: the dwelling house (provided that it is situated in Scotland), if the value of the house does not exceed $£ 473000$ (otherwise the sum of $£ 473000$ ), furniture and plenishing of the dwelling house (up to the value of $£ 29000$ ), a fixed sum of $£ 50000$. In addition, as a 'legal right' the surviving spouse takes one third of the deceased's remaining movable estate. The rest of the estate goes to the children.

\footnotetext{
${ }^{62}$ Belgium, Article 745 bis of the Belgian Civil Code.

${ }^{63}$ Articles 745a(1), subparagraphs 2 and 3, and Articles 746 to 755 of the Belgian Civil Code.

${ }^{64}$ Usufruct rights are not known per se in Finnish law.

${ }^{65}$ Finland, 3:1 PK.

${ }^{66}$ Article 757 of the French Civil Code.

${ }^{67}$ Sweden, 3:1 ÄB.

${ }^{68}$ Succession (Scotland) Act 1964, Section 8, modified by The Prior Rights of Surviving Spouse and Civil Partner (Scotland) Order 2011.
} 


\subsubsection{Rights of registered partners}

One of the main challenges in European succession law today is the position of nonmarried partners whether of same-sex or heterosexual partners. In most European countries, a clear differentiation is made between married couples and simple or registered partnerships both in civil law and in inheritance tax law.

In countries that have enacted same-sex marriages, heterosexual couples and homosexual couples have the same inheritance rights $\left(\right.$ Sweden $\left.^{69}\right)$.

In countries that grant the same rights to married couples and registered partnerships, such registered partnerships are generally reserved to same-sex couples: this is the case in Austria, ${ }^{70}$ Germany, ${ }^{71}$ Finland, ${ }^{72}$ England and Wales, ${ }^{73}$ and Ireland. $^{74}$

Some countries either do not recognize civil partnerships (Italy) or do not grant similar rights to married couples and registered partnerships. However in these countries, it is possible to foresee the devolution of the assets to the surviving partner through a will.

For example, in France, a registered partner is not considered as an heir of the deceased, he/she has only a right of undisturbed possession over the family home after the death of his/her partner. ${ }^{75} \mathrm{He} /$ she therefore only inherits if he/she is named as a beneficiary in the deceased's will. Where there are children, whether or not they are born to the couple, it is only possible to bequeath the available portion of the estate to the surviving partner. In the same manner, in Belgium, the surviving legal cohabitant has a right of usufruct in relation to the real estate in which the partners cohabited, as well as the right to use the furniture in the said property. The surviving legal cohabitant can however be deprived of this right of usufruct in the case of a will or gift inter vivos in favour of another person.

All European laws do not stipulate a share of the inheritance in the favour of a surviving partner of a de facto union and the partners of a non-registered partnership/de facto partnership can only become heirs in accordance with the provisions of a will.

\footnotetext{
${ }^{69}$ Örnsved [4], p. 733.

${ }^{70}$ Austria, §537a ABGB.

${ }^{71} \S 10$ of the Registered Partnerships Act; Lebenspartnerschaftsgesetz = LPartG. If the partnership has been registered abroad and German inheritance law applies by virtue of art. 25 EGBGB, the participation of the surviving partner in the inheritance depends on whether the foreign partnership is equivalent to the German partnership. When foreign inheritance law applies and it does not stipulate a statutory portion of the inheritance in the favour of the partner, the law of the State of registration applies to the partnership (lex libri) in a subsidiary capacity (art. 17b para. 1 EGBGB).

${ }^{72} \$ 8$ Finnish Registered Partnerships Act.

${ }^{73}$ UK Civil Partnership Act 2004.

${ }^{74}$ Civil Partnership and Certain Rights and Obligations of Cohabitants Act 2010.

${ }^{75}$ Article 763 of the French Civil Code.
} 


\subsubsection{Unworthiness to succeed}

All European legislations contain provisions on "unworthiness to succeed" ${ }^{76}$ In general, a person guilty of an offense against the deceased forfeits any forced heirship rights in the succession but may sometimes succeed as a legatee or as a legal heir.

This is the case in Ireland, where the offender does not have any legal right in the estate but may take a legacy under the will or benefit from a share on intestacy. ${ }^{77}$

On the contrary, in Finland, the offender loses the right to inherit, whether as an heir or as a universal successor. ${ }^{78}$

In Belgium, the surviving spouse may be disinherited if he/she has had an adulterine child, ${ }^{79}$ or under art. $915 \$ 3 \mathrm{CC}$ if four conditions are fulfilled (the spouses were separated for more than six months; a request for separate residences was made, a will disinheriting the other spouse and no taking up of common residence.

Notwithstanding forced heirship rules, many jurisdictions have instated rules on rights to alimony for the disinherited surviving spouse. This is the case in Belgium for disinherited spouses, ${ }^{80}$ and more generally in common law countries where the surviving spouse or other dependant of the deceased (child or partner) is entitled to reasonable financial provisions ${ }^{81}$ to enable the upholding of a standard of living.

\section{Reserved heirship rights}

This section shall look at the Principles of Forced Heirship (Sect. 2.1), The Types of Forced Heirship Rules (Sect. 2.2), The Beneficiaries of the Protection (Sect. 2.3), The Renunciation to Forced Heirship Rights (Sect. 2.4) and The Action in Abatement (Sect. 2.5).

\subsection{Principles of forced heirship}

According to Article 23 (2) of the Regulation: The law applicable to the succession shall govern in particular:

(a) the disposable part of the estate, the reserved shares and other restrictions on the disposal of property upon death as well as claims which persons close to the deceased may have against the estate or the heirs;

(b) any obligation to restore or account for gifts, advancements or legacies when determining the shares of the different beneficiaries.

\footnotetext{
${ }^{76}$ Comp. Article 463 of the Italian Civil Code; Article 726 of the French Civil Code; Irish Succession Act 1965, Section 120.

${ }^{77}$ Mee [3], p. 309, 315.

${ }^{78}$ Sundstrõm [6], p. 199, 200.

${ }^{79}$ Article 333 ter al. 3 and 4 Belgian Civil Code.

${ }^{80}$ Article 205 bis Belgian Civil Code.

${ }^{81}$ Inheritance (Provision for Family and Dependants) Act 1975.
} 
Forced heirship rules stricto sensu restrict the ability of a testator to decide how his assets should be distributed after his death. The content of the rules differ from country to country. Whilst some countries may insist that upon death all the property of an individual domiciled in that country must, in every circumstance, pass to their forced heirs, other countries may permit a testator to give away a proportion of his estate, provided the balance passes to forced heirs.

Reserved heirship rules aim to protect certain legal heirs from being purely and simply disinherited by their parent or child or spouse.

The financial security of the family is the most important need which gives the lawmaker cause for forced shares rules. The closest family members-spouse, descendants, parents - should be taken care of for a shorter or longer period after the death of the decedent.

Forced heirship rights may be calculated either as a proportion of the estate ${ }^{82}$ or as a proportion of the legal right to succeed. ${ }^{83}$ Forced heirship rights may constitute an ownership right ${ }^{84}$ or a simple claim ${ }^{85}$ to a portion of the estate.

\subsection{The types of forced heirship rules}

There are three types of forced heirship - the first type, forced heirship rules stricto sensu, adopted by (mostly) continental European countries ${ }^{86}$ and Scotland is where there are a number of categories of forced heirs. With a few exceptions, existence of heirs in a superior category means no inheritance for those in a lower category.

A second type of forced heirship rules, lato sensu, can be found in countries such as England, Wales ${ }^{87}$ and Northern Ireland, ${ }^{88}$ where there are no set portions or monetary values which forced heirs are entitled to. Instead dependants may be able to apply for financial provision out of the deceased's estate on the ground that the disposition of the deceased's estate effected by his/her will or the law relating to intestacy, is not such as to make reasonable financial provision for the applicant for their maintenance, education or advancement in life. The court may then make orders for payments out of the net estate or for the transfer of property.

The main difference between the two main types of forced heirship is that in the first case, in continental European countries and Scotland, the application of forced heirship rules is automatic whereas (generally) in common law countries, it is necessary to apply for financial provision out of the deceased's estate.

As a result, in England, Wales and Northern Ireland testators can leave assets to whomever they choose and this will only be contested if a dependant applies for financial provision out of the deceased's estate. On the contrary, in most European

\footnotetext{
${ }^{82}$ France and Italy.

${ }^{83}$ Germany, Nordic countries and Switzerland.

${ }^{84}$ Napoleonic law based legal systems.

${ }^{85}$ The Netherlands, Germany and Switzerland.

${ }^{86}$ Such as Belgium, Cyprus, France, Germany, Italy, the Netherlands, Portugal, Spain, Switzerland and Sweden.

${ }^{87}$ England and Wales, Inheritance (Provision for Family and Dependants) Act 1975.

${ }^{88}$ Inheritance (Provision for Family and Dependants) (Northern Ireland) Order 1979.
} 
countries, including Scotland, this is not the case. The laws of succession define specific rights for certain persons (the protected heirs). Whatever a will might say, it can easily be overturned by the protected heirs.

A third type of "forced heirship" rules, sui generis, may be found in Ireland, as a sort of a mixture of both main types. ${ }^{89}$ If the testator leaves a spouse and no children, the spouse shall have a legal right to one-half of the estate. ${ }^{90}$ This legal right takes priority over all other claims except those of creditors. ${ }^{91}$ If the testator leaves a spouse and children, the spouse shall have a legal right to one-third of the estate. There is no legal right granted to the children. However, where on application by or on behalf of the children of a testator, the court is of the opinion that the testator has failed in his/her moral duty to make proper provision for the children in accordance with his/her means, whether by his/her will or otherwise, the court may order that such provision shall be made for the children out of the estate as the court thinks just. ${ }^{92}$

\subsection{The beneficiaries of the protection}

In most countries, the children of the deceased and/or the spouse are protected, rarely the parents of the deceased. As stated above, forced heirship rules aim essentially to ensure the financial security of the closest family members-descendants, spouse, and parents-for a shorter or longer period after the death of the decedent. However, the current construction of many succession laws also implements the traditional transfer of assets from one generation to another in a vertical manner (transfer to the children) and/or aims at maintaining assets within the same family (transfer to the parents). In many European countries ascendants don't have forced heirship rights, ${ }^{93}$ even if such rights still exist in certain countries in a subsidiary manner. ${ }^{94}$

Some countries protect both spouse and children such as in England, Northern Ireland and Ireland. Under English law, or the law of Northern Ireland, ${ }^{95}$ both the spouse and the children are protected by the rules on alimony (reasonable financial provisions for dependants). ${ }^{96}$ Under Irish law, ${ }^{97}$ the spouse has a legal right to $1 / 3$ of the estate. There is no legal right granted to the children who may however claim in court that the testator has failed in his/her moral duty to make proper provision for the children in accordance with his/her means and thus claim a just provision.

Other countries protect primarily the children of the deceased, alternatively the spouse: this is the case in France and Belgium, but also in Finland and Sweden. Under Napoleonic based law, forced heirship rules apply to a portion of the estate,

\footnotetext{
${ }^{89}$ Mee [3], p. 309.

${ }^{90}$ Irish Succession Act, 1965, Section 111.

${ }^{91}$ Mee [3], p. 309, 312. - Irish Succession Act, 1965, Section 112.

${ }^{92}$ Irish Succession Act 1965, Section 117.

${ }^{93}$ Luxembourg and The Netherlands.

${ }^{94}$ Belgium, France, Germany.

95 Inheritance (Provision for Family and Dependants) (Northern Ireland) Order 1979.

${ }^{96}$ Hertel [2], p. 142, 146.

${ }^{97}$ Irish Succession Act, 1965, Section 111 (2).
} 
(generally $2 / 3$ of the estate) to protect the children of the deceased, alternatively the surviving spouse. In France, for example, the reserved portion for the deceased's children is half of the estate if the deceased leaves only one child at the time of his/her death. It is $2 / 3$ if he/she leaves two children and $3 / 4$ if he/she leaves three or more children. ${ }^{98}$ The reserved portion of the surviving spouse only exists where there are no descendants and if no divorce or separation procedure was initiated at the time of death. ${ }^{99}$ The surviving spouse's reserved portion is a quarter of the estate. ${ }^{100}$ Ascendants and collateral relatives are not forced heirs.

Belgium has a similar legislation yet however also protecting ascendants: a minimum portion (the reserved portion) of the succession must devolve to the children, then to the father and mother of the deceased and to the surviving spouse. ${ }^{101}$ This reserved portion is calculated as in France. ${ }^{102}$ If there are no descendants or a surviving spouse, the father and mother are each entitled to a quarter of the succession. The surviving spouse ${ }^{103}$ always receives a minima the usufruct of half of the assets comprising the inheritance. This half will include at least the usufruct of the property used as the main home and its furniture. These provisions are mandatory. The 1981 Belgian law ${ }^{104}$ grants this protection to the surviving spouse regardless of the existence of other heirs. Belgian law distinguishes between abstract and concrete reserved heirship rights. ${ }^{105}$ The abstract forced heirship rights are usufruct rights of $50 \%$ of the estate, whereas concrete forced heirship rights pertain to preferential assets notably the common home and furniture. The surviving spouse is entitled to the entire concrete forced heirship rights even if their value exceeds that of the abstract forced heirship rights. ${ }^{106}$ However, if one spouse has children from a former marriage, the spouses may agree, that the other spouse renounces his/her rights in the succession of the other (abstract forced heirship rights), except with respect to usufruct rights on the common home and furniture (concrete forced heirship rights). ${ }^{107}$

In Finland, only the descendants of the deceased may assert a right to a reserved portion. It is half of the statutory inheritance portion. ${ }^{108}$ The legatee may pay the reserved heir the equivalent of his/her reserved portion in cash as compensation. ${ }^{109}$ Irrespective of the law applicable to the inheritance, the surviving spouse may, if

\footnotetext{
${ }^{98}$ Article 913 of the French Civil Code.

${ }^{99}$ Art 914-1 French Civil Code.

${ }^{100}$ Article $914-1$ of the French Civil Code.

${ }^{101}$ Article 915 of the Belgian Civil Code.

${ }^{102}$ It amounts to half of the succession if there is one child (or descendant), $2 / 3$ where there are two children and $3 / 4$ if there are three or more children.

${ }^{103}$ The surviving cohabitee is not a forced heir.

${ }^{104}$ Law of 14 May 1981.

${ }^{105}$ Tainmont [7], p. 5.

${ }^{106}$ Article 915 bis $\$ 2$ al. 3 Belgian Civil Code.

${ }^{107}$ Article 915 bis $\S 2$ to 4 Belgian Civil Code.

${ }^{108}$ Finland, 7:1 PK-Sundstrõm [6], p. 199, 200.

${ }^{109}$ Finland, 7:5 PK.
} 
applicable, assert a right to use the last shared home, and both the children and the spouse may invoke a right to financial assistance. ${ }^{110}$

In Sweden, only the descendants of the deceased can assert a right to a reserved portion. ${ }^{111}$ It is half of the statutory inheritance portion. The reserved portion does not apply to certain parts of the estate, but to a share of the estate. It confers on the beneficiary the status of co-heir (statutory reserve). The surviving spouse will have, if applicable, a right to compensation established on the basis of the rule of the reserved portion (which cannot be limited by a testamentary provision). ${ }^{112}$

Other countries protect the children, the spouse and the ascendants: this is the case in Italy, Germany, Austria and Greece. Italian law sets down the right to reserved portions for the spouse of the deceased and his/her descendants and ascendants. If there is a child, he/she is entitled to the reserved portion of half of the estate; ${ }^{113}$ if there are several children they are entitled to two thirds. If there is a spouse and a child, the reserved portion is two thirds; if there is a spouse and several children, the reserved portion is three-quarters. ${ }^{114}$ If there are only ascendants, their reserved portion is one third. ${ }^{115}$ In the case where there are ascendants and a spouse, the reserved portion of the spouse is a half and that of the ascendants a quarter. ${ }^{116}$ In any case, the law stipulates that the spouse is entitled to live in the couple's home that is the property of the deceased or of both spouses, in addition to the right to use the movables. ${ }^{117}$

In Germany, the children and other descendants, the parents and spouse or surviving registered partner of the deceased are entitled to a reserved portion. ${ }^{118}$ The right of more distant descendants and the parents to a reserved portion is subordinate to the non-existence of (closer) descendants. ${ }^{119}$ The reserved portion represents the right to a payment amounting to half of the hereditary portion under the statutory inheritance.

In Austria, the reserved portion to which the children and surviving spouse of the deceased are entitled corresponds to half of their legal portion of inheritance. Parents are only entitled to the reserved portion if the deceased has not left any children; ${ }^{120}$ in this case, it is the equivalent of a third of the legal portion of inheritance. The reserved portion is a debt claim against part of the financial value of the estate.

In Greece, ${ }^{121}$ the reserved portion which limits the testator's right to dispose freely of his/her estate, amounts to half of the legal share in the inheritance for the surviving

\footnotetext{
${ }^{110}$ Finland, 26:12 PK-Sundstrõm [6], p. 199, 201.

${ }^{111}$ Sweden, 7:1 ÄB.

${ }^{112}$ Sweden, 3:3 ÄB.

${ }^{113}$ Article 537 of the Italian Civil Code.

${ }^{114}$ Article 542 of the Italian Civil Code.

${ }^{115}$ Article 538 of the Italian Civil Code.

${ }^{116}$ Article 544 of the Italian Civil Code.

${ }^{117}$ Article 540 of the Italian Civil Code.

${ }^{118}$ Germany, §2303 BGB, §10 par. 6 LPartG.

${ }^{119}$ Germany, §2309 BGB.

${ }^{120}$ Austria, \$762 ABGB.

${ }^{121}$ Article 1825 of the Greek Civil Code.
} 
spouse and the descendants of the deceased. If there are no descendants, the reserved portion passes to the ascendants, that is to say the deceased's parents.

Protection is given only with respect to certain assets in Scotland. Under Scottish law, the surviving spouse or civil partner and children are entitled to follow "legal rights" out of the deceased's movable estate. The surviving spouse takes one third of the deceased's movable estate if the deceased left children (or one half of it if the deceased left no children). The children take another one third of the deceased's movable estate if the deceased left a spouse or civil partner (or one half of it if the deceased left no spouse or civil partner). Each child has an equal claim.

It is to be noted that in many countries, the surviving spouse has a specific right to stay in the common home allowing his/her appropriation of the dwelling in which he/she has been ordinarily resident in at the time of death of the deceased. This right of appropriation also extends to household chattels. ${ }^{122}$

\subsection{The renunciation to forced heirship rights}

Historically it was not possible, under Napoleonic law, to renounce, in advance, the right to the reserved portion of the estate before the demise of the deceased. ${ }^{123}$ This renunciation could take place after the opening of the will (Belgium, Italy, Greece $^{124}$ ).

However more and more legislations allow such a renunciation. Since 2006, it is possible in France for any forced heir of adult age to renounce in advance his/her right to institute an action in abatement. ${ }^{125}$ Very strict formal conditions apply to this renunciation: it must be recorded in a deed executed before two notaries. It is signed separately by each party waiving his/her rights in this regard in the presence of the two notaries. It must indicate precisely the future legal consequences for each party waiving his/her rights and in particular explain that the renunciation to the reserved portion entails a renunciation to the whole of the succession.

German and Austrian law allow such a renunciation: by notarised contract with the testator ${ }^{126}$ or by filing a declaration before a court. ${ }^{127}$

A simple written declaration addressed to the testator is sufficient in Finnish ${ }^{128}$ and Swedish ${ }^{129}$ law, provided the heir receives sufficient compensation.

\footnotetext{
${ }^{122}$ Mee [3], p. 309, 313.

${ }^{123}$ Belgium, Art. 791 Civil Code.

${ }^{124}$ A notable exception exists in Greece for spouses of which only one holds Greek nationality and both live abroad: the lex Onassis (Art. 1 Ordinance 172/1974, in: Ferid/Firsching/Lichtenberger, Griechenland, Texte C II 2, S. 63) allows the foreign spouse to renounce any rights on the Greek's spouse's estate.

${ }^{125}$ France, Art. 929 Civil Code.

${ }^{126}$ Germany, §\$2346, 2348 BGB, Austria, §551 ABGB.

127 Austria, §551 ABGB.

${ }^{128}$ Finland, 17:1 PK.

${ }^{129}$ Sweden, 17:2 ÄB.
} 


\subsection{The action in abatement}

Heirs whose reserved portion has not been respected and who intend to assert their right to it must institute an action in abatement ${ }^{130}$ in order that donations and legacies exceeding the disposable portion of the estate are reduced.

The action in abatement must be filed within a certain deadline which ranges from 6 months (Finland ${ }^{131}$ and Sweden ${ }^{132}$ ) to 30 years (Belgium). For example, under French law, such an action may only be instituted by forced heirs within a period of 5 years after the opening of the succession or within 2 years after the date of discovery of the infringement. ${ }^{133}$ German law sets a time limit of three years that commences from the time the forced heir learns of the death and of the provision relating to his/her disinheritance. ${ }^{134}$ Under Austrian law, heirs must assert their right to the reserved portion before a court within three years. ${ }^{135}$ This period of prescription runs from the time the party entitled to inherit could have asserted his/her right. Italian law sets a time limit of 10 years.

Heirs may however waive their right to institute an action in abatement. ${ }^{136}$

Forced heirship rules may entail that any donations made up to thirty years before death ${ }^{137}$ are notionally added back to the deceased person's estate for the purpose of determining the amount of forced heirship shares. These are so-called "clawback provisions". The value of such gifts is in general valued not at the date of the gift but at the date of the deceased's death. ${ }^{138}$

For example in Belgium ${ }^{139}$ and France, ${ }^{140}$ if the request for abatement relates to previous donations, the most recent donations to date will first be reduced. If this request relates to legacies granted by a will, all the legacies will be reduced proportionally. However, if it relates to previous donations and legacies, the legacies will first have to be reduced before possibly having to reduce the previous donations.

In common law countries such as England and Wales, it is to be noted that lifetime transfer of property is governed by the lex situs and therefore does not fall into the deceased's estate that may be governed by a foreign lex successionis. Lifetime gifts are therefore excluded from the estate for the purposes of calculating the amount of forced heirship shares, as this property is not part of the estate at death.

\footnotetext{
${ }^{130}$ Comp. Belgium, Art. 920 et seq. Civil Code.

${ }^{131}$ Under Finnish law, forced heirs must assert their right to a reserved portion within 6 months after they become aware of the existence of the will.

${ }^{132}$ In order to assert his/her right to a reserved portion, the legal successor must request the amendment of the will (jämkning) within a period of six months of learning the content of the will (7:3 ÄB).

${ }^{133}$ Article 921 of the French Civil Code.

${ }^{134}$ Germany, $\$ \$ 195,199$ I BGB.

135 Austria, 1487 ABGB.

${ }^{136}$ Comp. France, article 929 of the French Civil Code.

${ }^{137}$ In some countries, ten years depending on statute of limitation rules.

${ }^{138}$ Belgium; Switzerland, art. 630 of the Swiss Civil Code.

${ }^{139}$ Belgium, Article 923 of the Belgian Civil Code.

${ }^{140}$ France, Article 932 of the French Civil Code.
} 
However under the Inheritance (Provision for Family \& Dependants) Act 1975, donations made in bad faith within six years of death, with intent to defeat claims under the 1975 Act may entitle the court to order the donee to make a payment or transfer property to provide a claimant with reasonable provision under the Act. Nevertheless, donees are only liable for the surviving traceable value of the gifted property still in their ownership.

Irish law is even more restrictive: courts may only review transactions made within three years of a person's death. ${ }^{141}$

\section{The transfer of the estate}

As a rule, in common law countries an executor (appointed by will) or administrator (appointed by court) must be appointed to administer the will. Such an administrator is not necessary in civil law countries where the succession is often managed by the heirs with assistance of a notary. The nomination of an administrator generally postpones the transfer of ownership on the assets of the estate. The moment of transfer of ownership (Sect. 1), the consequences of the acceptance (Sect. 2) or the renunciation (Sect. 3) to the succession and the liability of the heirs (Sect. 4) are regulated differently throughout Europe.

\subsection{The moment of transfer of ownership}

In many European civil law countries the transfer of ownership occurs at the time of death: the entire estate is devolved to the legal and forced heirs at the time of death, and this by virtue of the law. ${ }^{142}$ Acceptance of the succession is not necessarily express. It is tacit, when the heir signs a deed that necessarily implies his/her intention to accept and that he/she would only have the right to do as an heir, for example disposing of succession property. ${ }^{143}$ Some heirs must obtain a vesting order, ${ }^{144}$ in particular the State, specific legatees, residuary legatees and general legatees (except in the absence of forced heirs). To find out about their legacy, they must contact the heirs who have seisin. They take deliverance of their legacy through an intermediary.

In Common law countries, as a rule, transfer of ownership occurs after administration of estate. For example in Ireland, ${ }^{145}$ England and Wales, ${ }^{146}$ Northern Ireland $^{147}$ and Scotland: ${ }^{148}$ The real and personal estate of a deceased person shall on

\footnotetext{
${ }^{141}$ Irish Succession Act 1965, Section 121.

${ }^{142}$ Germany, see $\$ \$ 1922,1942$, par. 1 BGB; France article 724 para. 1 of the French Civil Code, Belgium, Art. 724 of the Belgian Civil Code; Greece, Article 1846 and 1711 of the Greek Civil Code; Finland.

${ }^{143}$ Belgium, Art. 778 of the Belgian Civil Code; France, art. 782 of the French Civil Code.

${ }^{144}$ Comp. French Civil Code article 724 para. 3.

${ }^{145}$ Mee [3], p. 309.

${ }^{146}$ Administration of Estates Act 1925, Section 36.

${ }^{147}$ Administration of Estates Act (Northern Ireland) 1955, Section 3.

${ }^{148}$ Succession (Scotland) Act 1964, Section 15.
} 
his/her death, notwithstanding any testamentary disposition, devolve on his/her 'personal representative'. ${ }^{149}$ The estate of a deceased person is administered by this personal representative. The personal representative pays the debts of the deceased and distributes the assets and transfers property to the beneficiaries.

A similar system exists in Sweden, where the succession does not automatically devolve to the heir or heirs after death. The succession is rather a legal entity, which is represented by an executor, a third party administrator or all the heirs jointly. The heirs must draw up an inventory of the estate within three months of the death of the deceased. The matrimonial property regime is settled subsequently. In Sweden, the legal matrimonial property regime is that of the deferred community of property. Finally, the deceased's debts are settled and the rest of the estate is shared.

Austria has an original system of transfer of ownership by court order. Under Austrian law, the acquisition of all property rights over the estate requires a writ of possession (by order of the courts). ${ }^{150}$ Prior to this order, a legal succession procedure is automatically instituted by a civil law notary on behalf of the courts. With this procedure the Austrian system differs from most EU Member States. Before an heir can acquire an estate, he/she must sign a declaration accepting the estate and provide proof of his/her entitlement to inherit.

Finally in Italy, the status of heir is acquired only when the heir accepts the succession, but legatees or devisees automatically acquire their status unless they renounce the inheritance.

Once an heir becomes aware of his/her entitlement, he/she may accept or renounce the succession.

\subsection{Acceptance of the succession}

In all European countries, acceptance may be unconditional or conditional.

For example, in France, the unconditional acceptance of a succession may be either express or tacit. ${ }^{151}$ An act which supposes the intention to accept and which cannot be accomplished by a person other than the heir is deemed to be an act implying acceptance. ${ }^{152}$ The disposal of a specific asset implies acceptance when the property in question is part of the estate. Administrative acts (except for provisional administrative acts and conservation measures) accomplished by an heir may also imply unconditional acceptance of the succession.

Conversely, in France, an heir may declare that he/she intends to accept the succession up to the amount of the net assets. ${ }^{153}$ The heir will be liable for the liabilities but only up to the value of the assets which devolve upon him/her in the succession. A declaration must be drawn up and filed with the clerk of the Court of First

\footnotetext{
${ }^{149}$ The personal representative is called 'executor', if he/she has been appointed by the testator in his/her will. The personal representative is called 'administrator', if he/she has been appointed by the probate court.

${ }^{150}$ Austria, $\$ 797$ ABGB.

${ }^{151}$ France, Article 782 of the French Civil Code.

${ }^{152}$ France, Article 783 of the French Civil Code.

${ }^{153}$ France, Article 787 of the French Civil Code.
} 
Instance in the judicial district where the succession has been opened. ${ }^{154}$ The declaration must be accompanied or followed by an inventory of the assets comprising the succession. The inventory must be drawn up by a civil law notary, an auctioneer or a bailiff. ${ }^{155}$ The inventory must be filed with the court within two months after the date of the declaration. If no inventory is drawn up, the succession will be deemed to have been unconditionally accepted. ${ }^{156}$ This inventory must include all assets and liabilities included in the succession. An heir may not opt to accept a succession up to the amount of the net assets if he/she has previously unconditionally accepted the succession.

A similar system exists in Belgium, ${ }^{157}$ where an heir who wishes to accept a succession under benefit of inventory must make a specific declaration to the Clerk of the Court of First Instance of the district in which the succession is opened. This declaration is registered in a special register and will subsequently have to be published in the Moniteur belge (Belgian official journal) in order to invite the deceased's creditors and possible legatees to assert their rights.

Creditors have specific rights in Austrian law when the heirs accept an estate without liability beyond the net assets. ${ }^{158}$ In this case, the judicial administrator will draw up an inventory of the estate and convene a meeting of creditors. ${ }^{159}$

\subsection{Renunciation to the succession}

In most countries, it is possible for the heirs to renounce the succession by making a relevant declaration in court ${ }^{160}$ or by a certified authentic declaration ${ }^{161}$ or with the judicial administrator. ${ }^{162}$

The deadline within which to make the renunciation varies greatly within Europe. For example, in Germany, the general deadline for renunciation is 6 weeks, ${ }^{163}$ and 6 months if, among others, the last residence of the deceased was exclusively abroad. ${ }^{164}$ In Greece, heirs must renounce an inheritance within four months from the time they become aware of the deceased's death and their title to the inheritance. ${ }^{165}$

\footnotetext{
${ }^{154}$ France, Article 788 of the French Civil Code.

${ }^{155}$ France, Article 789 of the French Civil Code.

${ }^{156}$ France, Article 790 of the French Civil Code.

${ }^{157}$ Belgium, Articles 793 et seq. of the Belgian Civil Code.

158 Austria, §802 ABGB.

${ }^{159}$ Austria, §165 Abs 2 Ausserstreitgesetz.

${ }^{160}$ Germany, $\$ 1945$ BGB; Austria, $\$ 805$ ABGB; France, Article 804 of the French Civil Code, Belgium, Art. 784 and seq. of the Belgian Civil Code.

${ }^{161}$ Germany, $\$ 1945$ BGB.

162 Austria, §805 ABGB.

163 Germany, §1944, par. 1 BGB.

${ }^{164}$ Germany, §1944, par. 3 BGB.

${ }^{165}$ Comp. Switzerland: 3 months from knowledge of the time of death (Art. 567 Swiss Civil Code).
} 
On the contrary, under French law, ${ }^{166}$ a heir must make a choice within ten years after the opening of the succession whereas under Belgian law, ${ }^{167}$ the deadline for renunciation is a maximum of 30 years, but it must be taken into account that acceptance of the succession can be tacit. Such a principle also applies in Finnish law where it is in theory possible to renounce a bequest without respecting a time limit, unless the beneficiary has previously accepted it (in a conclusive manner).

The renunciation is not subject to conditions. ${ }^{168}$

An heir who renounces a succession is deemed never to have been an heir. The revocation is retroactive. ${ }^{169}$

However, in some countries, any person entitled to inherit may withdraw his/her renunciation as long as the succession has not been accepted by another party. ${ }^{170}$

\subsection{The liability of heirs}

In most European countries, if the heir has unconditionally accepted his/her inheritance, his/her liability for the debts and liabilities of the deceased is, in principle, unlimited. ${ }^{171}$

In general, if there are several heirs, each heir is personally liable for the succession's debts and liabilities with respect to his/her share of the estate. ${ }^{172}$

However, he/she may be released from all or part of this liability for the succession's debts if, at the time of the succession, he/she could have been unaware of the existence of these liabilities and if the payments of the debts could have a serious effect on his/her personal assets. ${ }^{173}$

If an heir has accepted his/her inheritance up to the amount of net assets or under benefit of inventory, he/she is only liable for the succession's debts up to the value of the assets he/she has received. ${ }^{174}$

If the heir has renounced the succession, he/she has no liability for the debts. ${ }^{175}$

On the contrary, in Finland, the heirs are only responsible for the debts up to the value of the assets of the estate. ${ }^{176}$

\footnotetext{
${ }^{166}$ France, Article 780 if the French Civil Code.

${ }^{167}$ Belgium, Art. 789 Civil Code.

${ }^{168}$ Comp., Germany $\$ 1947$ BGB.

${ }^{169}$ Comp., France, article 805 Civil Code.

${ }^{170}$ France, article 807 Civil Code.

${ }^{171}$ Germany, $\$ 1967$ BGB; Austria, §801 ABGB; Belgium, Art. 724 of the Belgian Civil Code; France, article 785 of the French Civil Code; Greece; Italy.

${ }^{172}$ France, Article 873 of the French Civil Code; Greece; Italy.

${ }^{173}$ France, Article 786 para. 2 of the French Civil Code.

${ }^{174}$ Austria, $\$ 812$ ABGB; Belgium, Article 802 of the Belgian Civil Code; Greece; Italy; Switzerland, Article 589 of the Swiss Civil Code.

${ }^{175}$ Belgium, Article 785 of the Belgian Civil Code.

${ }^{176}$ Finland, 21: PK.
} 


\section{Conclusion}

By way of conclusion, the kaleidoscopic situation of succession law throughout Europe and the fact that the Regulation has a universal effect leading to the application of any law whether or not it is the law of a Member State ${ }^{177}$ will increase the need for proactive estate planning when the choice of law is open to the European resident. In addition to the issues developed above, many other legal issues await the practitioner notably with respect to the form of the will which varies considerably throughout Europe.

For example, in common law or in Nordic countries, the ordinary form of the testament is a private testament drawn up in presence of two witnesses. Civil law countries, such as Germany, accept the holograph will, ${ }^{178}$ the notarial will drawn up before a civil law notary, or by authentication of the last will, or by submission of a declaration of the deceased to the notary in which he/she certifies that the document is his/her last will. ${ }^{179}$

Common law countries do not have joint testaments (testament conjonctif or pacte successoral), however, it is possible to make a contract to make a will or not to make a will, with simple contractual effects. By comparison, in Denmark it is also possible to make a contract to make a will or not to make a will, with simple contractual effects $^{180}$ and a joint testament between spouses that cannot be revoked after the death of one of the spouses.

Most Napoleonic law countries, such as France, ${ }^{181}$ forbid joint testaments (testament conjonctif) and pactum on future successions whilst however sometimes recognizing such agreement made between foreigners.

German law allows for the pacte successoral (with anybody) and the testament conjonctif (only between spouses). Conversely, Austria allows for the pacte successoral, but only between spouses. Joint testaments are possible but may be revoked in a unilateral manner at any time.

As a result, in the future, an estate practitioner will not only have to be knowledgeable of the private international law rules set down in the new regulation, but also of the substantive law rules applicable to successions in the foreign jurisdictions of which his clients are nationals and finally also the formal rules applicable to the drafting of the last wishes of his clients.

The cross-border cooperation between legal professionals should thus increase significantly thanks to this new EU Regulation on Cross-Border Successions creating de facto a pool of expertise in comparative succession law, which may lead ultimately to European Best Practises in Estate Planning and a long dreamt of harmonisation of substantive rules.

\footnotetext{
${ }^{177}$ Regulation No 650/2012, Article 20. For a compendium of succession laws throughout Europe: www.successions-europe.eu.

${ }^{178}$ Germany, §2247 BGB.

${ }^{179}$ Germany, §2232 BGB.

${ }^{180}$ See also Sweden and Finland.

${ }^{181}$ But also Greece, Article 368 of the Greek Civil Code.
} 


\section{References}

1. Dörner, H., Lagarde, P. (eds.): Etude de Droit Comparé sur les Règles de Conflit de Juridictions et de Conflits de Lois Relatives aux Testaments et Successions dans les Etats Membres de 1'Union Européenne. Publication DNotI, Würzburg (2002)

2. Hertel, C.: Aperçu sur les systèmes juridiques dans le monde. In: Notarius International, vol. 1-2, pp. 142-156 (2009)

3. Mee, J.: Ireland. In: Hayton, D. (ed.) European Succession Laws, 2nd edn., pp. 305-322. Jordan, Bristol, (2002)

4. Örnsved, P.: Suède, rapport national. In: Dörner, H., Lagarde, P. (eds.) Etude de Droit Comparé sur les Règles de Conflit de Juridictions et de Conflits de Lois Relatives aux Testaments et Successions dans les Etats Membres de 1'Union Européenne, pp. 707-744. Publication DNotI, Würzburg (2002)

5. Revillard, M.: Droit International Privé et Communautaire: Pratique Notariale, 7th edn. Defrénois, Paris (2010)

6. Sundstrõm, Z.: Finland. In: Hayton, D. (ed.) European Succession Laws, 2nd edn., pp. 197-210. Jordan, Bristol (2002)

7. Tainmont, F.: Le droit successoral belge. Electron. J. Comp. Law 14(2) (2010). Available at: http://www.ejcl.org/142/art142-10.pdf

8. Van Erp, S.: New developments in succession law. Electron. J. Comp. Law 11(3) (2007). Available at: http://www.ejcl.org/113/article113-5.pdf 